\title{
Assessment of Microbiological Quality and Efficacy of Gbogbonise Epa Ijebu Herbal Remedy on Some Uropathogens
}

Enitan S. $\mathrm{S}^{1 *}$, Uduchukwu O. $\mathrm{E}^{1}$, Gotep $\mathrm{J}^{2}$, Effiong E. J. ${ }^{1}$, Ileoma E. $\mathrm{O}^{1}$, Mensah-Agyei G. $\mathrm{O}^{3}$, Adetiloro E. $\mathrm{O}^{3}$, Adekunbi O. $\mathrm{A}^{1}$, Odigie J. $\mathrm{O}^{1}$, Adetola A. $\mathrm{O}^{1}$

${ }^{1}$ Department of Medical Laboratory Science, Babcock University, Ilishan-Remo, Nigeria

${ }^{2}$ Department of Drug Development, National Veterinary Research Institute, Vom, Nigeria

${ }^{3}$ Department of Microbiology, Babcock University, Ilishan-Remo, Nigeria

DOI: $10.36348 /$ sijtcm.2022.v05i01.002 $\quad$ | Received: 05.11.2021 | Accepted: 07.01.2022 | Published: 24.01 .2022

*Corresponding author: Enitan S. S

Department of Medical Laboratory Science, Babcock University, Ilishan-Remo, Nigeria

\section{Abstract}

Background: Gbogbonise Epa Ijebu is a commercially sold native concoction in South-West, Nigeria, with the potential of curing many ailments as claimed by the manufacturer and vendors. This study investigated the antimicrobial quality and efficacy of Gbogbonise Epa Ijebu. Materials and Methods: A total of 20 samples of the herbal remedy were purchased from local vendors in Ilishan-Remo Community of Ogun State, Nigeria and were assessed for their microbiological quality using standard microbiological methods. Also, the efficacy of the herbal remedy was tested against some selected uropathogens using the Punch-hole agar diffusion method. Data generated were analyzed using the Instant GraphPad software package and P value $<0.05$ was considered statistically significant. Results: The outcome of the study shows that half $(50 \%)$ of the herbal remedy samples examined were sterile, while the other half $(50 \%)$ were contaminated with a microbial count of $<10 \mathrm{CFU} / \mathrm{mL}$. The microbial isolates recovered from the herbal remedy include: Staphylococcus aureus (8.3\%), Coagulase negative Staphylococcus (75\%) and Microsporium spp (16.7\%). Assessment of the antimicrobial potential of the herbal remedy show that the test herbal remedy had strong inhibitory activity against Staphylococcus aureus $(17 \pm 0.6 \mathrm{~mm})$, Escherichia coli $(16.3 \pm 0.3 \mathrm{~mm})$, Pseudomonas aeruginosa $(16.3 \pm 0.3 \mathrm{~mm})$, Klebsiella pneumoniae $(15 \pm 0.6 \mathrm{~mm})$ and Proteus mirabilis $(14 \pm 0.8 \mathrm{~mm})$, except Candida albican, at a concentration of $200 \mathrm{mg} / \mathrm{mL}$. The combined herbal solution and standard drug gave higher zone diameter of inhibition: Klebsiella pneumoniae $(25 \pm 0.6 \mathrm{~mm})$, Pseudomonas aeruginosa $(24 \pm 0.6 \mathrm{~mm})$, Staphylococcus aureus $(23.7 \pm 0.3 \mathrm{~mm})$, Escherichia coli $(23.3 \pm 0.3 \mathrm{~mm})$ and Candida albican $(15 \pm 0.6 \mathrm{~mm})$, except Proteus mirabilis. The Minimum Inhibitory Concentration (MIC) and Minimum Bactericidal/Fungicidal Concentration (MBC/MFC) of the herbal remedy for all the test isolates (except Candida albican) was $100 \mathrm{mg} / \mathrm{mL}$ and $200 \mathrm{mg} / \mathrm{mL}$, respectively. The result of the phytochemical screening showed the presence of alkaloids, anthraquinones, cardiac glycosides, flavonoids, saponins and tannins, while steroids and resins were absent. Conclusion: The outcome of this study further strengthens the claim of efficacy made by the manufacturer and vendors of the herbal remedy. However, more attention should be given to quality preparations, packaging and storage in view of the general safety of the consumers.

Keywords: Gbogbonise Epa Ijebu, Herbal Remedy, Microbiological Quality, Efficacy, Uropathogens.

Copyright (C) 2022 The Author(s): This is an open-access article distributed under the terms of the Creative Commons Attribution 4.0 International License (CC BY-NC 4.0) which permits unrestricted use, distribution, and reproduction in any medium for non-commercial use provided the original author and source are credited.

\section{INTRODUCTION}

Herbal medicine is the oldest known method of healing using the roots, barks, and leaves of numerous plants [1]. Today, herbal remedies are available as powders, liquids, or combinations that can be consumed raw or cooked, as well as ointments, liniments, and incisions to treat various ailments, infections and injuries [2]. The growing usage of plant extracts in the food, cosmetics, and pharmaceutical sectors implies that a thorough research of medicinal plants is critical for identifying active chemicals. Many researchers have discovered that the components of various higher plants have antibacterial activities [3, 4].

Urinary tract infections (UTIs) are infections caused by the presence and proliferation of one or more microorganisms in the urinary system, which includes the urethra, bladder, ureters, and kidneys [5]. An infection of the urinary system can affect both the lower 
Enitan S. S et al., Sch Int J Tradit Complement Med, Jan, 2022; 5(1): 7-18

and upper tracts, or possibly both [6]. Urinary pathogens, or simply uropathogens, are microorganisms whose presence and activity in any region of the urinary system can cause disease states such as cystitis (bladder infection) and pyelonephritis (kidney infection) [7]. UTIs have been linked to a large range of uropathogens. Although the distribution of microorganisms that cause UTI is shifting, Escherichia coli remains the most common cause of UTI [8]. $90 \%$ of all UTIs in ambulatory individuals and $50 \%$ of nosocomial UTIs are caused by E. coli [9]. Other uropathogens include: Pseudomonas, Proteus, and Klebsiella species amongst others [9-11].

In the past, early treatment for UTIs consisted mostly of herbal therapies, along with bed rest to alleviate symptoms, as recorded in the Ebers papyrus from ancient Egypt [12]. Several herbs have been reported to exert either bacteriostatic or bactericidal activity on uropathogens. However, the rising incidence of antibiotic-resistant bacteria, as well as the rising expense of antibiotic therapy in recurrent UTIs, has sparked interest in the use of herbal remedies in the treatment of UTIs [7, 13-16].

Urinary tract infection (UTI) is a common health problem among many Nigerians, men and women inclusive. Unfortunately, emergence and reemergence of antibiotic resistant urinary pathogens have resulted in treatment failure, prolong hospital-stay and increase in cost of treatment. In Nigeria, herbal medicine is still being used by over $80 \%$ of the population. Many indigenous plants are harvested and used to cure ailments and mend injuries [17].

Today, many commercially sold herbal remedies are available in the markets (standardized and non-standardized, under different brand names and some do not even have brand names) which the manufacturers claim to be more effective than the conventional antibiotics. Gbogbonise Epa Ijebu is an example of such herbal remedies commonly sold in Ogun State, Southwest Nigeria. The herbal remedy is considered an economic and accessible treatment option for many ailments by the locals. The manufacturers claim it is an "All-purpose magic" drug that can cure more than 200 infections including urinary tract infection (UTI), with little or no side effects, hence its name.

Due to the disparity in the potency of different batches of herbal remedies, as well as emergence and re-emergence of antibiotic resistant uropathogens, there is therefore a strong need to verify and re-verify the claims made by the manufacturers of these herbal remedies with regard to their microbiological quality and efficacy. While the production and sales of standardized herbal remedies is being encouraged by the World Health Organization (WHO), the need to assured their microbiological quality and efficacy cannot be overemphasized. And even though the antimicrobial potential of Gbogbonise Epa Ijebu herbal remedy may have been investigated in the past, very little is known about the sensitivity of uropathogens to this herbal remedy. To the best of our knowledge, no work has been done to investigate the combined effects of Gbogbonise Epa Ijebu and standard drugs on uropathogens. Dearth of information in this regard necessitate this research.

\section{MATERIALS AND METHODS Study Design} agar plates.

This is an in vitro experimental study using

\section{Duration of study}

The study lasted for a period of 2 months (September-October, 2020).

\section{Study Area}

The research was conducted at Babcock University, Ilishan-Remo, Ogun State, in the Medical Microbiology Laboratory Unit of the Department of Medical Laboratory Science, School of Public and Allied Health, a Seventh-day Adventist institution of higher learning. Ilishan-Remo community is a geopolitical ward in Ikenne Local Government Section of Ogun State, located in the tropical area of Nigeria's south-western region at $7^{\circ} 29^{\prime} 00^{\prime \prime} \mathrm{N} 2^{\circ} 53^{\prime} 00^{\prime \prime} \mathrm{E}$. Trading and farming are the most common jobs among the residents, and they are known for cultivating rubber, cocoa, cashew nuts, plantains, and other agricultural items. Despite the availability of dependable medical services, the local population continues to rely on plants as medicines for both curative and prophylactic purposes.

\section{Ethical Approval}

Ethical approval was sought for and obtained from the Babcock University Health Research Ethics Committee (BUHREC) before the commencement of the study. (Ethical Approval Registration Number: BUHREC 185/20).

\section{Test Herbal Product}

Samples of Gbogbonise Epa Ijebu 200 Cure herbal remedy was procured from local vendors in Ilishan-Remo Community of Ogun State and was transported to the Medical Microbiology Laboratory Unit of the Department of Medical Laboratory Science, Babcock University, Ilishan-Remo, Ogun State. The herbal remedy comes in a paste form. Each bottle contains $100 \mathrm{ml}$ of the herbal paste (Figure 1). 


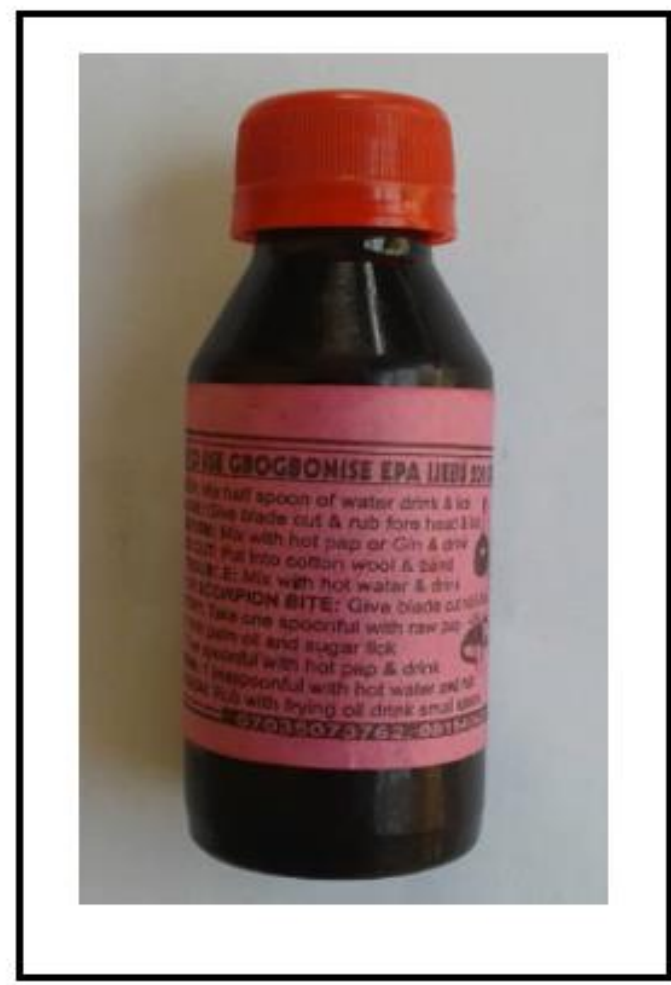

Figure 1: Gbogbonise Epa Ijebu 200 Cure (Source: Photo Credit to Enitan, S. S.)

\section{Physical Examination of test herbal remedy}

Upon purchase of the test herbal remedy, the product was physically examined for the following: Manufacturer's Details, active Ingredients, volume, physical evidence of deterioration e.g. colour and odour, expiry date, National Agency for food and Drug Administration and Control (NADFAC) registration number etc.

\section{Source of Standard drugs Antibacterial Agent}

Ciprofloxacin® (Geltec Pvt Ltd, India) was purchased from the Pharmacy Unit, Babcock University Teaching Hospital, Ilishan-Remo, Ogun State. To prepare twenty (20) $\mathrm{mL}$ of the Ciprofloxacin ${ }^{\circledR}$ suspension, 20 tablets of $500 \mathrm{mg}$ Ciprofloxacin ${ }^{\circledR}$ was dissolved in $20 \mathrm{~mL}$ of sterile distilled water to obtain a concentration of $500 \mathrm{mg} / \mathrm{mL}$.

\section{Antifungal Agent}

Nystatin ${ }^{\circledR} \quad$ (Geltec Pvt Ltd, India) was purchased from the Pharmacy Unit, Babcock University Teaching Hospital, Ilishan-Remo, Ogun State. To prepare twenty (20) $\mathrm{mL}$ of Nystatin ${ }^{\circledR}$ suspension, 20 tablets of $20 \mathrm{mg}$ Nystatin ${ }^{\circledR}$ was dissolved in $20 \mathrm{~mL}$ of sterile distilled water to obtain a concentration of 20 $\mathrm{mg} / \mathrm{mL}$.

\section{Assessment of microbiological quality of the herbal remedy \\ Sterility test \\ Method described by Okunlola et al. [18] was} used to detect the presence of potential bacterial and fungal contaminants in the herbal remedy paste. Briefly, the mouth of each sealed bottle of the herbal preparation was sterilized by rapidly passing it through the flame of the bursen burner thrice before opening to prevent self-contamination. Afterwards, about $0.1 \mathrm{~g}$ of each sample of herbal remedy paste was streaked directly on the plates containing Nutrient Agar (NA) medium and Sabouraud Dextrose Agar (SDA) medium already prepared according to manufacturer's standard. The NA plate was incubated at $37^{\circ} \mathrm{C}$ for three days, while the SDA plate was incubated at room temperature $\left(25^{\circ} \mathrm{C}\right)$ for seven days. Five or more colonies on either plate indicate contamination of the test herbal remedy paste. Bacterial and Fungal isolates was identified using standard microbiological methods.

\section{Identification of Bacterial Isolates}

After incubation, plates containing cultured samples were examined and colonies of bacteria were identified by Gram-stain, motility test and routine biochemical tests such as determining the fermentation of glucose, lactose and sucrose in the triple sugar iron medium, urea hydrolysis, producing indole from tryptophan, use of citrate, producing hydrogen sulfide, oxidase, catalase and coagulase production as described by Cheesbrough [19]. The results of the above tests were entered into IDENTAX bacterial identifier (a free software developed using Sun Microsystems's Java Technology) for the taxonomical identification of bacteria isolates using phenotypical characteristics.

\section{Identification of Fungal Isolates}


Enitan S. S et al., Sch Int J Tradit Complement Med, Jan, 2022; 5(1): 7-18

Fungal isolates were identified on the basis of macroscopic (with the aid of an Atlas of Mycology) and microscopic characteristics (using Gram staining, Lactophenol cotton blue staining and Germ tube test).

\section{Preparation of herbal Remedy Solution}

The herbal remedy was brought out from the refrigerator, allowed to warm to room temperature and properly mixed before use. The concoction (which is in paste form) was reconstituted using sterile distilled water.

\section{Phytochemical Screening of herbal solution}

The test herbal solution was subjected to preliminary phytochemical screening for the detection of various plant constituents using methods described by Sofowora [20], as well as Trease and Evans [21].

\section{Test for Alkaloids}

A $1 \mathrm{~mL}$ of the herbal solution was stirred with $3 \mathrm{~mL}$ of $1 \%$ aqueous hydrochloric acid on a steam bath and filtered. $1 \mathrm{~mL}$ of the filtrate was treated with few drops of the following reagents: Mayer's reagent, Wagner's reagent and Draggendorf's reagent. Precipitation (Cream, Reddish-brown or Orange or reddish-brown) with either of these reagents was taken as preliminary evidence for the presence of alkaloids.

\section{Test for Tannins}

A $1 \mathrm{~mL}$ of the herbal solution was stirred with $1 \mathrm{~mL}$ of distilled water and filtered. Ferric chloride solution was added to the filtrate. A blue-black, green or blue-green precipitate was taken as the evidence for the presence of tannins.

\section{Test for Resins}

A $2 \mathrm{~mL}$ of the herbal solution was added to 5 $\mathrm{mL}$ of boiling ethanol. This was filtered through Whatman No. 1 filter paper and the filtrate was diluted with $4 \mathrm{~mL}$ of $1 \%$ aqueous $\mathrm{HCl}$. Formation of resinous precipitate indicates the presence of resins.

\section{Test for Steroids}

About $1 \mathrm{~mL}$ of the herbal solution was added to $2 \mathrm{~mL}$ of chloroform; sulphuric acid was carefully added to form a lower layer. A reddish-brown color at the inter-phase will indicate the presence of steroidal ring.

\section{Test for Anthraquinones}

A $1 \mathrm{~mL}$ of herbal solution was taken into a dry test tube and $5 \mathrm{~mL}$ of chloroform was added and shook for 5 minutes. It was filtered and the filtrate was thoroughly mixed with equal volume of $100 \%$ ammonia solution. Pink violet or red colour in the ammoniacal layer (lower layer) indicates the presence of free anthraquinones.

\section{Test for Saponins}

About $1 \mathrm{~mL}$ of the herbal solution was thoroughly mixed with water in a test tube. Frothing which persists on warming was taken as a preliminary evidence for presence of saponins.

\section{Test for Flavonoids}

A $2 \mathrm{~mL}$ of herbal solution was detanned with acetone. The sample was placed on a hot water bath for all traces of acetone to evaporate. Boiling distilled water was added to the detanned sample. The mixture was filtered while hot. The filtrate was allowed to cool and $5 \mathrm{~mL}$ of $20 \%$ sodium hydroxide was added to equal volume of the filtrate. A yellow solution indicates the presence of flavonoids.

\section{Test for Cardiac Glycosides}

A $1 \mathrm{~mL}$ of the herbal solution was added to 1 $\mathrm{mL}$ of glacial acetic acid containing one drop of ferric chloride solution. A $1 \mathrm{~mL}$ of concentrated sulphuric acid was added gently by the side of the test tube. A brown ring obtained at the inter-phase indicates the presence of deoxy-sugar characteristic of cardenolides.

\section{Determination of microbial load in herbal remedy}

The surface viable count as described by Miles and Misra [23] was used for the determination of microbial load in the herbal remedy samples.

\section{Assessment of microbiological efficacy of the herbal remedy solution \\ Test Isolates}

The Medical Microbiology Laboratory of the Babcock University Teaching Hospital (BUTH), Ilishan-Remo, Ogun State, provided stock cultures of the test isolates. Out-patients with symptomatic UTIs and bacteruria of less than $10^{5} \mathrm{CFU} / \mathrm{mL}$ were used to collect the test organisms. Patients' "clean catch" midstream urine (MSU) samples were collected in sterile disposable universal bottles and cultured on appropriate bacteriologic media (Nutrient Broth (NB), MacConkey agar (MCA), Blood Agar (BA), Mannitol Salt Agar (MSA), and Cystein Lactose Electrolyte Deficient (CLED) Agar supplied by Oxoid) and incubated at $37^{\circ} \mathrm{C}$ for $18-24$ hours with informed consent and permission from Gram stain, Sugar fermentation tests, and Biochemical testing were used to characterize the bacteria growths, as described by Cheesbrough [19]. The isolates were identified by Bergey's Manual for Determinative Bacteriology [22]. Pure isolates were sub-cultured on agar slants for antimicrobial testing of the herbal remedy solution.

\section{Standardization of Inoculum}

Five colonies from each isolate's pure culture were inoculated into nutritional broth (NB) and incubated for 18 to 24 hours at $37^{\circ} \mathrm{C}$. The surface viable count was performed according to Miles and Misra's instructions [23]. The bacterial/fungal suspension's turbidity was adjusted to meet that of the $0.5 \mathrm{McF}$ arland 
Enitan S. S et al., Sch Int J Tradit Complement Med, Jan, 2022; 5(1): 7-18

standard $\left(10^{5} \mathrm{CFU} / \mathrm{mL}\right)$ by diluting it $1: 100$ in sterile nutritional broth.

\section{Preparation of different concentration of herbal remedy solution}

The paste herbal cure was reconstituted with sterile distilled water by dissolving two $(2 \mathrm{~g})$ of the paste herbal remedy in $10 \mathrm{ml}$ of distilled water to achieve a $200 \mathrm{mg} / \mathrm{mL}$ concentration. To generate lower quantities of the herbal cure solution $(100 \mathrm{mg} / \mathrm{mL}$ and $50 \mathrm{mg} / \mathrm{mL})$, a twofold dilution process was used. All of this was done in an aseptic manner. The solutions were stored in the fridge until they were used.

\section{Agar diffusion test}

Agar diffusion test using punch-hole method described by slack [24] was used to determine the susceptibility of the test isolates to the herbal solution.

Table 1: Experimental pharmacological protocol

\begin{tabular}{|l|l|}
\hline Well No. & Treatments \\
\hline 1 & It received $10 \mu \mathrm{g} / \mathrm{mL}$ of Ciprofloxacin or Nystatin (positive control) \\
\hline 2 & It received sterile normal saline (Negative control) \\
\hline 3 & It received $200 \mathrm{mg} / \mathrm{mL}$ of herbal suspension \\
\hline 4 & It received $100 \mathrm{mg} / \mathrm{mL}$ of herbal suspension \\
\hline 5 & It received $50 \mathrm{mg} / \mathrm{mL}$ of herbal suspension \\
\hline 6 & $\begin{array}{l}\text { It received equal mixture }(50: 50) \text { of } 200 \mathrm{mg} / \mathrm{mL} \text { of herbal suspension }+10 \mu \mathrm{g} / \mathrm{mL} \text { Ciprofloxacin or } \\
\text { Nystatin }\end{array}$ \\
\hline
\end{tabular}

\section{Minimum inhibitory concentration (MIC)}

The minimum inhibitory concentration was determined using the tube dilution method described by Cowan and Steel [25].

\section{Minimum bactericidal/fungicidal concentration (MBC/MFC) test \\ Minimum \\ Bactericidal/Fungicidal \\ Concentration (MBC/MFC) Test was determined as described by Baron and Fingold [26].}

\section{Data analysis}

Data that were obtained for the antimicrobial activities of the herbal solution (i.e., Zones diameter of inhibition) are presented using tables and expressed as mean and standard deviation of triplicates. These were statistically analyzed using GraphPad software package. $P$ values $<0.005$ were considered significant [27].

\section{RESULTS}

Twenty (20) samples of the Gbogbonise Epa Ijebu 200 Cure herbal remedy were purchased from local vendor in Ilishan-Remo Community of Ogun State and were assessed for their microbiological quality and efficacy. The herbal remedy is commercially packaged as a black semi-solid paste in $100 \mathrm{~mL}$ capacity bottle. Physical examination of the herbal remedy shows that the manufacturer's name and contact address, active ingredients, manufacture date, expiry date, batch number, as well as NADFAC registration number were not provided. Indications for the herbal remedy include: Stomach ache, Headache, Rheumatism, Sore, Cuts, Snake bite, Scorpion bite, Dysentery, Cough, Pile, Chest pain, Convulsion etc. (Table 2).

Ten $(50 \%)$ out of the 20 samples examined were free from microbial contaminants, whereas the other ten $(50 \%)$ samples had microbial contaminants.
There was no significant difference $(\mathrm{P}=0.100)$ in the number of samples with or without microbial contaminants (Table 3). The microbial load recovered from the test herbal remedy were graded based on the colony forming unit CFU/mL. 10 (50\%) out of the 20 samples examined had a microbial count of $0 \mathrm{CFU} / \mathrm{mL}$ (i.e., they were contaminant free). While the other ten samples $(50 \%)$ had acceptable level of contamination, with a microbial count of $<10 \mathrm{CFU} / \mathrm{mL}$. Interestingly, none had unacceptable level of contamination $(>100$ $\mathrm{CFU} / \mathrm{mL})$. There was no significant difference $(\mathrm{P}=0.100)$ in the number of samples free from microbial contaminants and those with acceptable level of microbial contaminants (Table 4).

The frequency of microbial contaminants present in the test herbal remedy is presented in Table 5 Coagulase negative Staphylococcus was the most isolated bacterial contaminant (75\%), Microsporium spp (16.7), while the least was Staphylococcus aureus $(8.3 \%)$. The only fungal contaminant recovered from the test herbal remedy samples was Microsporium spp $(10 \%)$. The result of the phytochemical screening done on the test herbal remedy is presented in Table 6 . Alkaloids, Anthraquinones, Cardiac glycosides, Flavonoids, Saponins and Tannins were present, while Steroids and Resins were absent.

The anti-microbial activity of herbal remedy on selected test isolates is presented in Table 7 The herbal remedy solution failed to show a concentration dependent inhibitory activity on all the test isolates as only the highest concentration $(200 \mathrm{mg} / \mathrm{mL})$ tested had effect on all the bacterial test isolates but not on the fungal isolate (Candida albican). Staphylococcus aureus was the most sensitive to the herbal remedy with mean \pm SEM zone diameter of inhibition of $17 \pm 0.6 \mathrm{~mm}$, followed by Escherichia coli and Pseudomonas aeruginosa $(16.3 \pm 0.3 \mathrm{~mm})$, Klebsiella pneumoniae 
Enitan S. S et al., Sch Int J Tradit Complement Med, Jan, 2022; 5(1): 7-18

$(15 \pm 0.6 \mathrm{~mm})$ and lastly, Proteus mirabilis $(14 \pm 0.8$ $\mathrm{mm})$. There was no significant difference $(\mathrm{P}>0.05)$ in the inhibitory activity of the herbal solution on Staphylococcus aureus when compared to those of Escherichia coli and Pseudomonas aeruginosa. However, there was when compared to Klebsiella pneumoniae and Proteus mirabilis $(\mathrm{P}<0.01)$. Meanwhile, Candida albican was found to be resistant to the herbal solution with no zone diameter of inhibition.

Furthermore; when the herbal solution was combined with standard drug, a partial synergistic effect was observed. The combined herbal solution and standard drug gave higher zone diameter of inhibition for the test isolates: Klebsiella pneumoniae $(25 \pm 0.6$ $\mathrm{mm})$, Pseudomonas aeruginosa (24 $\pm 0.6 \mathrm{~mm})$, Staphylococcus aureus $(23.7 \pm 0.3 \mathrm{~mm})$, Escherichia coli $(23.3 \pm 0.3 \mathrm{~mm})$ and Candida albican $(15 \pm 0.6 \mathrm{~mm})$, except Proteus mirabilis which was found to be resistant with no zone diameter of inhibition which indicates antagonist effect between the standard drug and the herbal solution. The effect of the combined herbal remedy and standard drug solution was found to be significantly higher than that of the herbal remedy solution alone when tested singly $(\mathrm{P}<0.001)$. The positive control (Ciprofloxacin) for the bacterial test isolate showed a zone diameter of inhibition ranging from $21 \pm 0.6 \mathrm{~mm}$ to $24 \pm 0.6 \mathrm{~mm}$, while the positive control (Nystatin) for Candida showed a zone diameter of $22 \pm 0.6 \mathrm{~mm}$.

The Minimum Inhibitory Concentration (MIC) and Minimum Bactericidal/Fungicidal Concentration (MBC/MFC) of the test herbal remedy on the uropathogens is presented in Figure 2. There were no MIC and MFC for Candida albican, as it was found to be the resistant to the herbal remedy solution. Escherichia coli, Pseudomonas aeruginosa, Staphylococcus aureus, Klebsiella pneumoniae and Proteus mirabilis all had the same MIC and MBC, of $100 \mathrm{mg} / \mathrm{mL}$ and $200 \mathrm{mg} / \mathrm{mL}$, respectively.

Table 2: Details of Gbogbonise Epa Ijebu herbal remedy

\begin{tabular}{|l|l|}
\hline Parameter & Remark \\
\hline Manufacturer's Name/Contact address & Not provided \\
\hline Indication & $\begin{array}{l}\text { Stomach ache, Headache, Rheumatism, Sore, Cuts, Snake bite, Scorpion } \\
\text { bite, Dysentery, Cough, Pile, Chest pain, Convulsion }\end{array}$ \\
\hline Active ingredients & Not provided \\
\hline Volume & $100 \mathrm{~mL}$ \\
\hline Physical appearance & Black semi-solid paste \\
\hline Manufacture date & Not provided \\
\hline Expiry date & Not provided \\
\hline Batch Number & Not Provided \\
\hline NAFDAC No. & Not provided \\
\hline
\end{tabular}

Table 3: Frequency of microbial contamination in Gbogbonise Epa Ijebu herbal remedy

\begin{tabular}{|l|l|l|l|}
\hline $\begin{array}{l}\text { No of samples examined } \\
\text { N }(\%)\end{array}$ & $\begin{array}{l}\text { No. of samples contaminated } \\
\text { N }(\%)\end{array}$ & $\begin{array}{l}\text { No. of samples not contaminated } \\
\text { N }(\%)\end{array}$ & P-Value \\
\hline $20(100)$ & $10(50)$ & $10(50)$ & 0.100 \\
\hline
\end{tabular}

$P$-value $>0.05$ is considered not to be statistically significant.

Table 4: Microbial loads recovered from Gbogbonise Epa Ijebu herbal remedy

\begin{tabular}{|l|l|l|l|l|}
\hline \multicolumn{4}{|l|}{ Grades of Microbial Counts } \\
\hline $\begin{array}{l}\text { 0 CFU/mL } \\
\text { N (\%) }\end{array}$ & $\mathbf{1 0}$ CFU/mL & $\begin{array}{l}\mathbf{1 1 - 1 0 0} \text { CFU/mL } \\
\mathbf{N}(\%)\end{array}$ & $>\mathbf{1 0 0} \mathbf{~ C F U / m L ~}$ & P-Value \\
\hline $10(50)$ & $10(50)$ & $0(0)$ & $0(0)$ & 0.100 \\
\hline
\end{tabular}

Key: $C F U / m L=$ Colony forming Unit per $m L, N=$ Number of samples examined, \% = Percentage. NB: Microbial count of $0 \mathrm{CFU} / \mathrm{mL}=$ microbial free (sterile culture), Microbial count $<10 \mathrm{CFU} / \mathrm{mL}=$ Acceptable level of contamination,

Microbial count between 11-100 CFU/mL = Inconclusive, Microbial Count $>100 \mathrm{CFU} / \mathrm{mL}=$ Unacceptable level of contamination. There was no significant difference in the number of samples that were microbial-free and those with $<10$ CFU/mL microbial counts. $P$-value $>0.05$ is considered not to be statistically significant.

Table 5: Frequency of microbial contaminants present in Gbogbonise Epa Ijebu herbal remedy

\begin{tabular}{|l|l|l|l|}
\hline Organism & Isolate & Frequency $(\mathbf{N})$ & Percentage (\%) \\
\hline \multirow{2}{*}{ Bacteria } & Staphylococcus aureus & 1 & 8.3 \\
\cline { 2 - 4 } & Coagulase negative Staphylococcus & 9 & 75.0 \\
\hline Fungi & Microsporium spp. & 2 & 16.7 \\
\hline
\end{tabular}


Table 6: Phytochemicals Present in Gbogbonise Epa Ijebu herbal remedy

\begin{tabular}{|l|l|}
\hline Phytochemicals & Result \\
\hline Alkaloids & + \\
\hline Anthraquinones & + \\
\hline Cardiac glycosides & + \\
\hline Flavonoids & + \\
\hline Resins & - \\
\hline Saponins & + \\
\hline Steroids & - \\
\hline Tannins & + \\
\hline
\end{tabular}

Key: $+=$ Presence, $-=$ Absence

Table 7: Anti-microbial activity of Gbogbonise Epa Ijebu herbal remedy on selected test isolates

\begin{tabular}{|c|c|c|c|c|c|c|}
\hline \multirow{3}{*}{ Isolates } & \multicolumn{6}{|c|}{ Mean \pm SEM Zone Diameter of Inhibition (mm) } \\
\hline & \multicolumn{3}{|c|}{ Concentration of herbal remedy tested $(\mathrm{mg} / \mathrm{mL})$} & \multirow{2}{*}{$\begin{array}{l}\text { Herbal Remedy + } \\
\text { Standard Antimicrobial }\end{array}$} & \multicolumn{2}{|l|}{ Control } \\
\hline & 200 & 100 & 50 & & Positive & Negative \\
\hline $\mathrm{EC}$ & $16.3 \pm 0.3$ & 0 & 0 & $23.3 \pm 0.3$ & $22.7 \pm 0.3$ & 0 \\
\hline $\mathrm{PA}$ & $16.3 \pm 0.3$ & 0 & 0 & $24 \pm 0.6$ & $23.3 \pm 0.3$ & 0 \\
\hline S A & $17 \pm 0.6$ & 0 & 0 & $23.7 \pm 0.3$ & $24 \pm 0.6$ & 0 \\
\hline KP & $15 \pm 0.6$ & 0 & 0 & $25 \pm 0.6$ & $23.7 \pm 0.3$ & 0 \\
\hline $\mathrm{PM}$ & $14 \pm 0.8$ & 0 & 0 & 0 & $21 \pm 0.6$ & 0 \\
\hline $\mathrm{CA}$ & 0 & 0 & 0 & $15 \pm 0.6$ & $22 \pm 0.6$ & 0 \\
\hline
\end{tabular}

Key: $E C=$ Escherichia coli, $P A=$ Pseudomonas aeruginosa, $S A=$ Staphylococcus aureus, $K P=$ Klebsiella pneumoniae, $P M=$ Proteus mirabilis, $C A=$ Candida albican, Negative Control $=$ Sterile normal saline, Positive control for bacterial isolate =10ug Ciprofloxacin, Positive control for Fungal isolate = 10ug Nystatin.

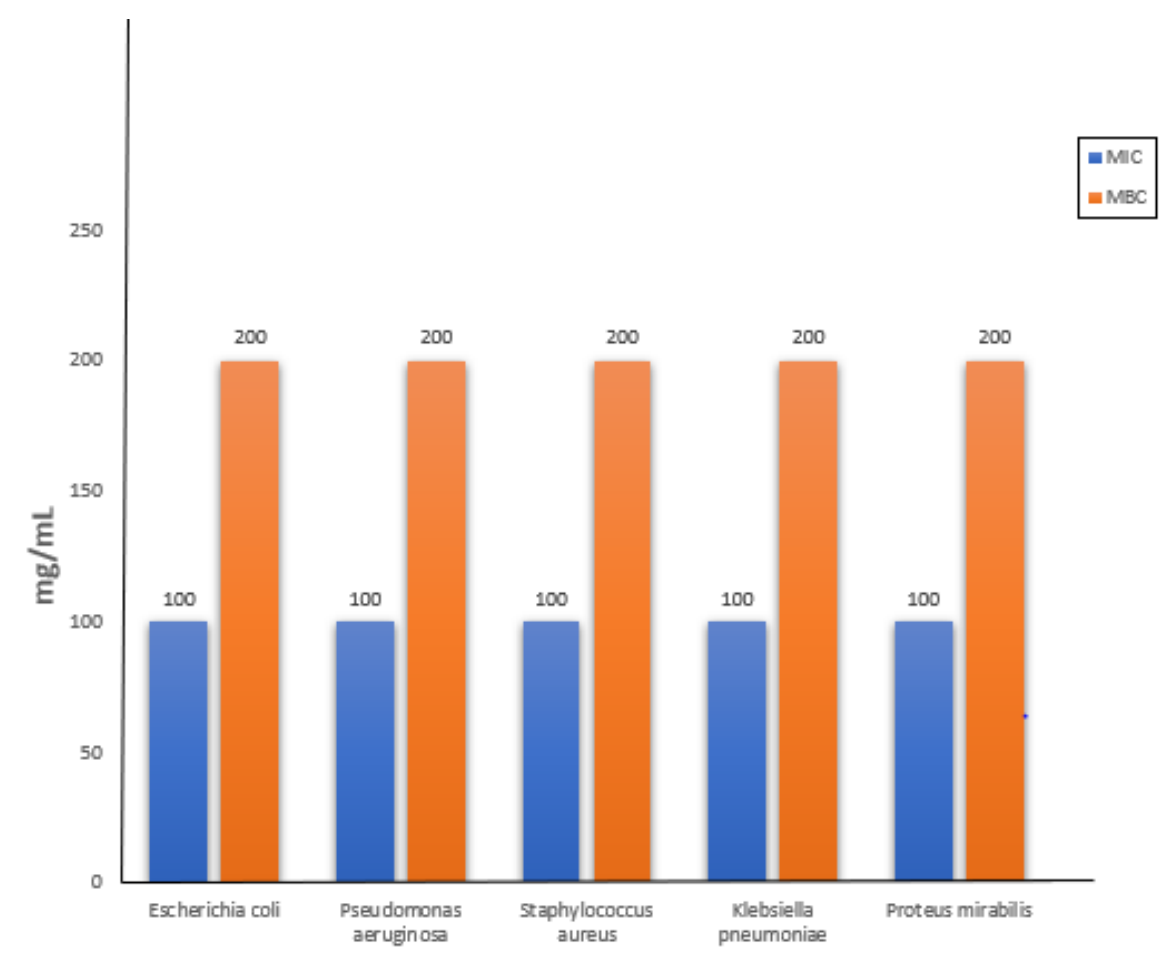

Figure 2: A bar chart showing the Minimum Inhibitory Concentration (MIC) and Minimum Bactericidal Concentration (MBC) of Gbogbonise Epa Ijebu herbal remedy on uropathogens 


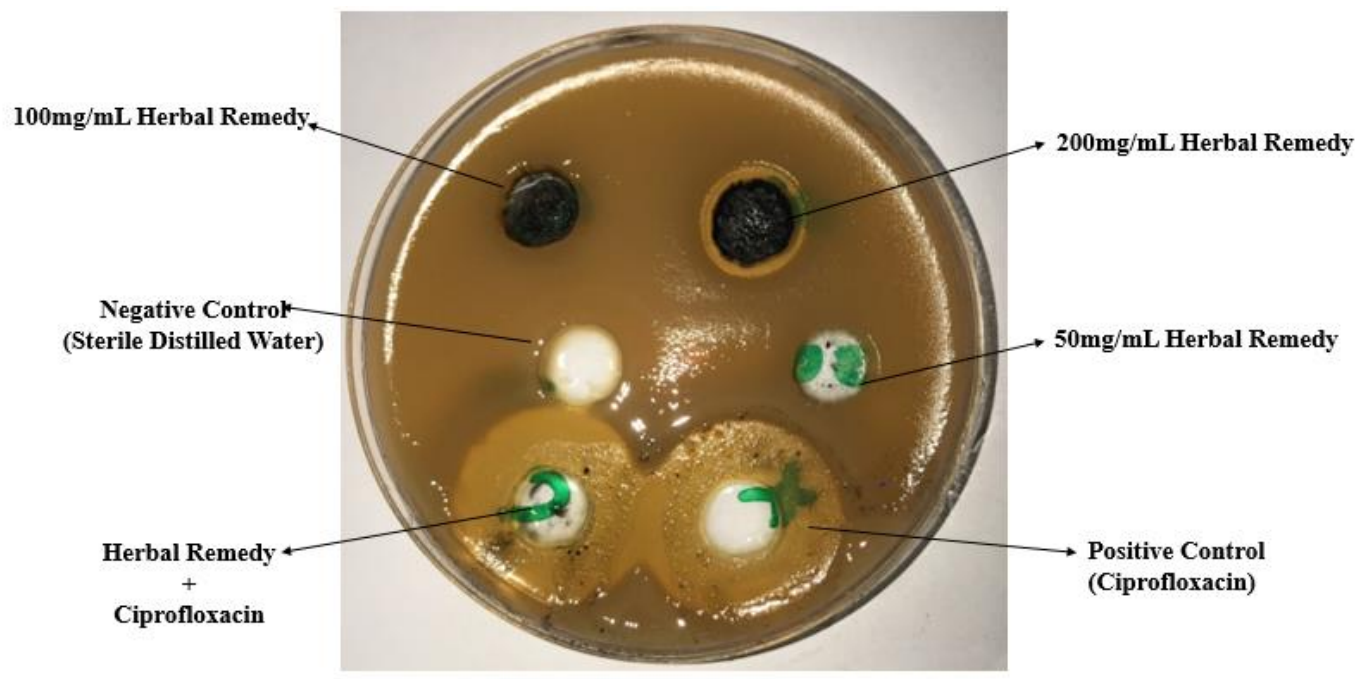

Figure 3: Picture showing the zone of inhibition of Gbogbonise Epa Ijebu Herbal Remedy on E. coli

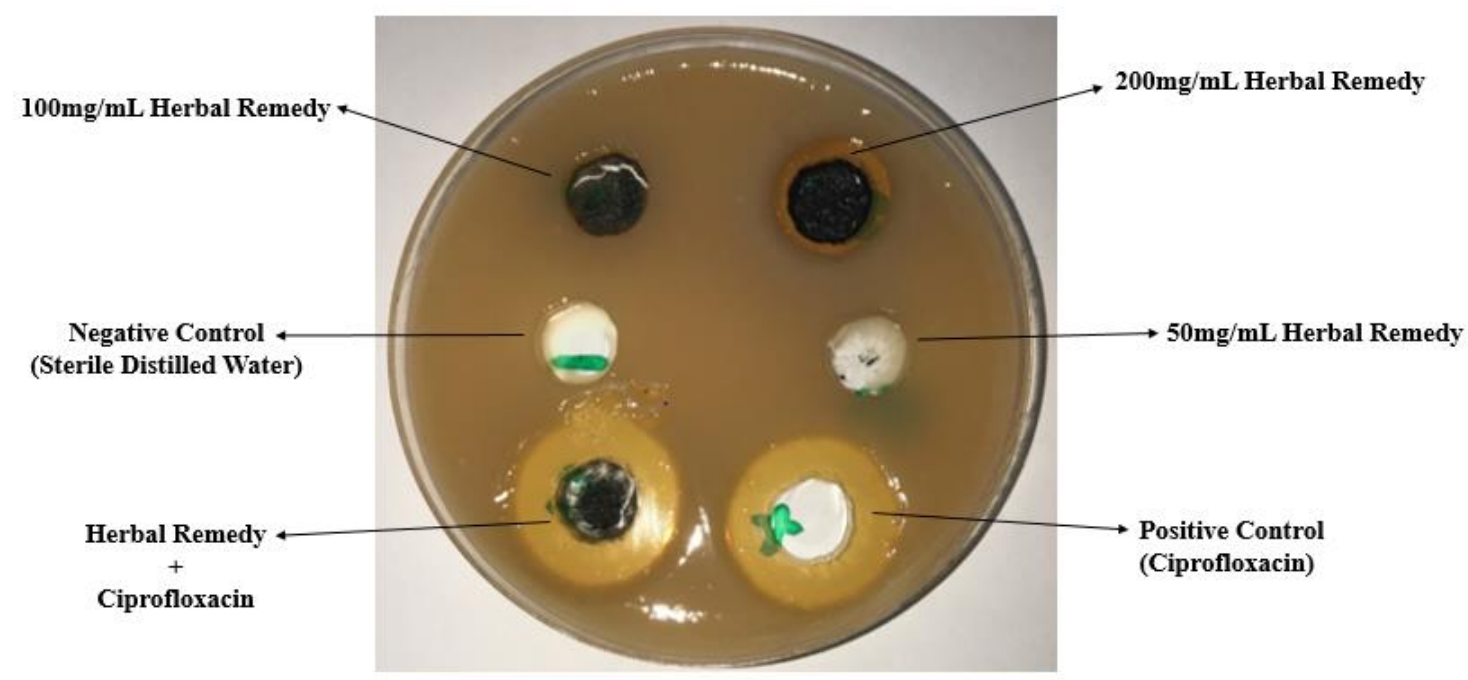

Figure 4: Shows the zone of inhibition of Gbogbonise Epa Ijebu Herbal Remedy on K. pneumoniae

\section{DISCUSSION}

Gbogbonise Epa Ijebu is a commercially sold herbal remedy in Southwest Nigeria. It is considered a "wonder" drug that cures a lot (if not all) of ailments, hence its name. This study assessed the microbiological quality and efficacy of Gbogbonise Epa Ijebu on some selected uropathogens. Half of the samples of the herbal remedy examined in this study were sterile (50\%), while the other half were not $(50 \%)$. Even though the mean microbial load of all the contaminated samples tested was low $(<10 \mathrm{CFU} / \mathrm{mL})$, it still suggests the herbal remedy do not meet the drug standard which excludes the presence of indicator, index and pathogenic organism in products to be consumed by the general populace [28].

Possible sources of microbial contamination of the herbal remedy could be attributed to diverse factors. These include; the producer/handler's own normal flora, bags, wristwatch/ bracelet, clothes, shoes, poor hygiene amongst the producers/handlers of these products either along the line of production, packaging, storage or transportation which is an important factor that can contribute to the occurrence of microbial contaminants in the test herbal remedy, activities such as talking, yawning, sneezing, coughing during production contributes to the presence of the microbial contaminant in the herbal remedy. Most people in Nigeria do not practice good hand hygiene which is thorough washing of hands with clean water and soap after making use of the toilet, before or after eating. The human hands harbor a lot of pathogenic bacteria when not washed or sanitized properly, it becomes a good medium for transfer of microbial contaminants to whatever that is being handled thereby exposing the user to this pathogenic microorganism [29].

In addition to that, the manufacturer's materials and equipment such as the herbs, grinder, mixer, cooking utensils, water, dryers, containers and other ingredients use for preparing the test herbal remedy could serve as a viable origin for microbial 
Enitan S. S et al., Sch Int J Tradit Complement Med, Jan, 2022; 5(1): 7-18

contaminants. House-keeping activities, using a dirty environment in the production or dispensing rooms can aerosolize particles containing microorganisms. This can also be responsible for the occurrence of microbial contaminants in our test herbal remedy [30, 31].

The amount of physical activity, the source of ventilation, the relative humidity/ambient temperature, the rate of air exchange, inappropriate exposure of production materials to contaminants and absence of acceptable standard in the facilities where the herbal remedy is produced and packaged, the density of occupants (i.e., number of person per square area) amongst other factors could have added to the occurrence of microbial contaminants in the test herbal remedy assessed in this study. Since, organisms like Staphylococcus aureus, Coagulase negative staphylococcus, as well as Microsporium spp (Greyish white, flat spreading, velvety, light salmon pink to reddish-brown on reverse, with chlamydospores and no conidia) were found to be present in the herbal remedy on culturing, it simply suggests that the preparation/production of the herbal remedy did not following standard best practices. Therefore, it is of high importance to maintain and use a healthy and safe environment in the production and packaging of this herbal product. Although a low microbial load was recorded in the test herbal remedy, it may pose no risk to most people, those with a compromised immune system may be at risk of infection.

This herbal remedy (Gbogbonise Epa Ijebu) has proved to be great source of phytochemicals. The results of the qualitative phytochemical screening indicated the presence of medicinally active secondary metabolites in the test herbal remedy such as alkaloids, tannins, anthraquinones, saponins, flavonoid and cardiac glycosides which were also reported by Adeleye et al. [32]; Adeleye et al. [33]; and Belonwu et al. [34]. Although, steroids and resin were absent. Phytochemicals have been documented to be the major biologically active principles in medicinal plants exhibiting various physiological activities and are widely used in the human therapy, veterinary, agriculture, scientific research and in countless other areas [35].

The phytochemicals identified in this study have earlier proven to be bioactive. Saponins for instance, are steroids common in large number of plants and plant products that play an important role in human and animal nutrition which include; hypoglycemic activity, viricidal activity, anti-hypertensive activity, anti-inflammatory, immune stimulating remedies, antitumor, hypolipidemic/hypoglycemic activity [36, 37]. Flavonoids are important group of polyphenols known to inhibit the initiation, promotion and progression of tumors. Flavonoids have been reported to exert multiple biological effects including antimicrobial, antidiarrheal, antioxidant, free radical scavenging abilities, anti-inflammatory, anticarcinogenic and can be used as basic medicinal agent because of their analgesic and antispasmodic properties [38].

Still, the alkaloid are the largest group of secondary chemical constituents and most effective plant substances used therapeutically because of their well-documented antimicrobial, anthelminthic and antidiarrheal activities. The solutions of alkaloids are intensely bitter. It functions in the defense of plants against herbivores and pathogens and are widely exploited as pharmaceuticals, stimulants, narcotics and poison due to their potent biological activities. They play some metabolic role and control development in living system [7].

Anthraquinones contain the following qualities; antimicrobial, antioxidant, emetic, insecticidal and gives plants its laxative qualities which brings about constipation relief. Tannins on the other hand, are phenolic compounds also known for their antimicrobial, anti-helmintic and anti-diarrheal activities. They are used as antiseptic and this activity is due to presence of the phenolic group. The phenolic acids in tannin act essentially by helping in the reduction of particular adherence of organisms to the cells lining the bladder, which ultimately lowers the incidence of urinary-tract infection. The presence of tannins in herbs and herbal products has been documented to support their strong use for treatment of candidiasis, however the test herbal remedy in this study did not demonstrate any anticandidal activity, which may likely be due to low concentration of tannin present [39].

Cardiac glycosides are a unique group of secondary metabolites that comprises the most druglike molecules subjected to several investigations and proved to be fruitful in developing potential drugs. They are used to treat congestive heart failure or cardiac failure, atrial arrhythmia $[40,41]$. The presence of the above listed compounds has been confirmed by previous workers to possess anticarcinogenic, antiinflammatory, antioxidant, antidiarrheal, free radical scavenging abilities and antimicrobial activities which could be responsible for the efficacy of the herbal remedy in treatment of different ailments [35, 42, 43].

The outcome of this study shows that the test herbal remedy Gbogbonise Epa Ijebu displayed antibacterial activity on all the bacterial isolates tested. However, it failed to demonstrate antifungal activity against Candida albican. This implies that cases of candidiasis cannot be treated with the herbal remedy. On the other hand, Nystatin (Standard antifungal drug) when tested singly against $C$. albican gave a zone diameter of inhibition of $22 \pm 0.6 \mathrm{~mm}$, which was further reduced $(15 \pm 0.6 \mathrm{~mm})$ when combined with the test herbal remedy. Since the combined action of herbal remedy-drug solution is lesser than that of the drug 
Enitan S. S et al., Sch Int J Tradit Complement Med, Jan, 2022; 5(1): 7-18

(Nystatin) when used alone, it can be concluded that the herbal-drug interaction was indifference, instead of being addictive or synergistic. Although some herbal remedies have been shown to possess anticandidal activity through inhibition of lipid synthesis [44, 45], not Gbogbonise Epa Ijebu as observed in this study.

The presence of diverse zones diameter of inhibition on the agar plates shows the comparable susceptibility of the test isolates and the antimicrobial activity of the test herbal remedy at the highest concentrations tested. When the herbal remedy was combined with Ciprofloxacin (a standard antibacterial drug), the combined action was not significantly different compared to when used alone for all the bacterial isolates tested, except Proteus mirabilis in which the combined action of the herbal remedy and Ciprofloxacin resulted in no zone diameter of inhibition $(0 \mathrm{~mm})$, while the single action of Ciprofloxacin gave a zone diameter of inhibition of $21 \pm 0.6 \mathrm{~mm}$. The combination of herbal remedy with antibiotics leading to partial or total synergism has been reported previously by Didry et al. [46]. The lack of activity against Proteus mirabilis when the herbal remedy was combined with Ciprofloxacin indicates an antagonistic effect and will require further investigation.

At the highest concentration $(200 \mathrm{mg} / \mathrm{mL})$ tested, the herbal remedy gave zone diameter of inhibition which are comparable to that exhibited by our controls (Ciprofloxacin and Nystatin). This gives credence on the effectiveness of the test herbal remedy. Wide zone diameter of inhibition exhibited by the herbal remedy solutions on Escherichia coli, Pseudomonas aeruginosa, Staphylococcus aureus, Klebsiella pneumoniae and Proteus mirabilis; suggest the infections induced by these test isolates may respond favorably in vivo as shown in our efficacy studies. While on the other hand, the no zone of inhibition observed with Candida albican even at the highest concentration of the test herbal remedy (200 $\mathrm{mg} / \mathrm{mL}$ ), indicates that the organism is not susceptible to the test herbal remedy or that a higher concentration (>200 mg/mL) of the herbal remedy solutions will be required to obtain a significant zone of inhibition. This further explains that at $\leq 200 \mathrm{mg} / \mathrm{mL}$, treatment failure and persistent infection by $C$. albicans should be expected and at $\geq 200 \mathrm{mg} / \mathrm{mL}$ cytotoxicity of the epithelial cells found in the urinary tract may occur. This suggest that the herbal remedy may not be an effective antimicrobial agent for Urinary Tract Infections caused by $C$. albicans. The lack of sensitivity of Candida albican to the test herbal remedy as observed in this study may be as a result of its inherent resistance and the inability of the herbal remedy to block lipid synthesis in the organism [45]. Lack of anticandidal activity in vivo has been associated with the ability of the organism to decrease drug intracellular accumulation/concentration, up-regulation of target enzyme, target site alteration, decreased target affinity/processivity for the drug or counteraction of the drug effect $[47,48]$.

Since half of the herbal remedy samples examined had a microbial count of $<10 \mathrm{CFU} / \mathrm{mL}$, this suggest that there may be batch-to-batch variation, hence the need to optimize the quality control and assurance system in the production line.

The Minimum Inhibitory Concentration (MIC) gave the lowest concentration of the herbal remedy solutions that inhibits the growth of the test isolates. All the test isolates except Candida albican had an MIC of $100 \mathrm{mg} / \mathrm{mL}$. This shows that a concentration higher than $100 \mathrm{mg} / \mathrm{mL}$ will be required to eliminate the test organisms completely.

The Minimum Bactericidal/Fungicidal Concentration gave the highest dilution that yielded no single bactericidal/fungal colony on the solid medium. All the test isolates except Candida albican had an MBC of $200 \mathrm{mg} / \mathrm{mL}$ which represent bacteriocidal activity of the test herbal remedy. All the bacterial isolates tested showed higher MBC than MIC, this indicates that higher concentration of the test herbal remedy solution was required to eliminate the microbes than that needed to suppress their growth.

\section{CONCLUSION}

The outcome of this study show that the test herbal remedy is effective against a variety of uropathogens (Escherichia coli, Pseudomonas aeruginosa, Staphylococcus aureus, Klebsiella pneumoniae, and Proteus mirabilis, except Candida albican) with mean inhibition zones ranging from 14 to $24 \mathrm{~mm}$. This underscore the health claim made by the makers and vendors of the herbal remedy. However, more attention should be given to quality preparations, packaging and storage in view of the general safety of the end users.

\section{BIBLIOGRAPHY}

1. Shulz, V., Rudolf, H., \& Mark, B. (2001). Medicinal plants, Phytomedicines and Phytotherapy. In their rational phytotherapy; a physician's guide to herbal medicine. $4^{\text {th }}$ ed. Berlin, New York, Springer, pp. 1-39.

2. Onyeagba, R. A., Ugbogu, O. C., Okeke, C. U., \& Iroakasi, O. (2004). Studies on the antimicrobial effects of garlic (Allium sativum Linn), ginger (Zingiber officinale Roscoe) and Lime (Citrus aurantifolia Linn). Afr J Biol, 3, 552-554.

3. Misra, T. N., Sigh, R. S., Pandey, N. S., Prasal, C., \& Singh, B. P. (1992). Antifungal essential oil and a long chain alcohol from Achyranthis aspera. Phytochemistry, 31, 1811-1812.

4. El-Shouny, W. A. \& Magaam, S. (2009). Sensitivity of multidrug resistant Pseudomonas aeruginosa isolated from surgical wound-infections 
Enitan S. S et al., Sch Int J Tradit Complement Med, Jan, 2022; 5(1): 7-18

to essential oils and plant extracts. World J. Med. Sci., 4: 104-111.

5. Akinyemi, K. O., Alabi, S. A., Taiwo, M. A., \& Omonigbehin, E. A. (1997) "Anti-microbial susceptibility pattern \& plasmid profiles of pathogenic bacteria isolated from subjects with urinary tract infections in Lagos, Nigeria". Nigeria Quarterly Journal of Hospital Medicine, 1, 7-11.

6. Gupta, K., Hooton, T. M., Naber, K. G., Wullt, B., Colgan, R., Miller, L.G., Moran, G.J., Nicolle, L., E., Raz, R., Schaeffer, A., J., \& Soper, D. E. (2011). International clinical practice guidelines for the treatment of acute uncomplicated cystitis and pyelonephritis in women. Diseases. Clin. Infect. Dis., 52(5), 103-120.

7. Enitan, S. S., Olley, M., Uhunmwangho, S. E., Akele, R. Y., Ehiaghe, A. F., \& Enitan, C. B. (2014). Antibacterial activity of methanolic leaf extract of Plunenetia conophora Mull. Arg. against selected bacteria isolated from urinary tract infection. International Journal of Microbiology \& Application, 1(1), 1-10.

8. Ojiegbe, G. C., \& Nworie, W. C. (2000). "Asymtomatic bacteriuria among school pupils in Enugu Urban Areas”. Journal of Medical Science, 9, 42-46.

9. Cheesbrough, M. (2006a). "Examination of urine: Possible pathogens" In: Cheesbrough, M. (ed.). District Laboratory Practice in Topical Countries, Part 2. Cambridge University Press, Cape Town, South Africa. pp. 105-113.

10. McGuckin, M. (2012). The patient survival guide: 8 simple solutions to prevent hospital and healthcare-associated infections. New York, NY: Demos Medical Publishing, 25(4), 1.

11. Lo, E., Nicolle, L. E., Coffin, S. E., Gould, C., Maragakis, L. L., \& Meddings, J. (2014). Strategies to prevent catheter-associated urinary tract infections in acute care hospitals. Infection Control Hospital. Epidemiology, 35, 464-479.

12. Nickel, J. C. (2005a). "Management of urinary tract infections: historical perspective and current strategies: part 1 - before antibiotics". The Journal of Urology, 173(1): 21-26.

13. Nickel, J. C. (2005b). "Management of urinary tract infections: historical perspective and current strategies: part 2 - modern management". The Journal of Urology, 173(1), 27-32.

14. Al-Achi, A. (2008). "An introduction to botanical medicines: history, science, uses, \& dangers". Westport, Conn.: Praeger Publishers, pp. 126.

15. Enitan, S. S., Digban, K. A., Olley, M., Otuneme, O. G., Faloye, T. G., \& Adediji, I. O. (2016). Curative and nephrotoxic potential of methanolic leaf extract of Plukenetia conophora Mull arg. in rats challenged with Pseudomonas aeruginosa urinary tract infection. International Journal of Herbal Medicine, 4(4), 49-58.

16. Smith, R. D., Yago, M., Millar, M., \& Coast, J. (2006). "A macroeconomic approach to evaluating policies to contain antimicrobial resistance: A case study of methicillin resistant staphylococcus aureus (MRSA)". Appl. Health Econ. Health Policy, 5(1), 55-65.

17. Akerele, O. (1992). "WHO guidelines for the assessment of herbal medicines". Fitoterapia, 60, 99-110.

18. Okunlola, A., Adewoyin, B. A., \& Odeku, O. A. (2007). Evaluation of pharmaceutical \& microbial qualities of some herbal medicinal products in south western Nigeria. Tropical Journal of Pharmaceutical Research, 6(1), 661-670.

19. Cheesbrough, M. (2006b). "Biochemical tests to identify bacteria" In: Cheesbrough, M. (ed.). District Laboratory Practice in Topical Countries, Part 2. Cambridge University Press, Cape Town, South Africa. pp. 62-70, 180.

20. Sofowora, A. (1982). Medicinal plants and Traditional medicine in Africa. John Wiley, Chichester. pp. 179.

21. Trease, G. E., \& Evans, W. C. (1996). Phenols and phenolic glycosides in: Trease and Evans London (eds). Pharmacognosy (13th edn). Biliere tindall, pp. 832-833.

22. Buchanan, R. E., \& Gribbons, N. E. (1974). Bergey's Manual of Determinative Bacteriology (8th edition). Williams \& Wilkins Co. Baltimore USA.

23. Miles, A. A., \& Misra, S. S. (1938), Bacterial counts. Journal of Hygiene (London), 38, 732.

24. 'Slack, M. P. E. (1985). "Practical aspects of antimicrobial chemotherapy". In: Weatherall, D. J., Warrel, D. A., \& Ledingham, J. G. G. (eds.). Oxford Textbook of Medicine, 1, 530-543.

25. Cowan, S. T., \& Steel, K. J. (1985). 'Antibiotic Sensitivity' In: Cowan \& Steel's Manual for Identification. Cambridge University Press London New York, pp. 24.

26. Baron, J. E., \& Fingold, S. M. (1990). "Methods for testing antimicrobial effectiveness" In: Bailey Scotts Diagnostic Microbiology. Mosby, C. V. (ed.), Missouri, pp. 171-194.

27. Shott, S. (1990). "Statistics for health professionals". Saunders, W.B., Co. Philadelphia, pp. 313-336.

28. Mamatha, D., \& Kumar, G. N. (2017). Preparation, Evaluation and Comparison of Herbal Toothpaste with Markedly Available Tooth Pastes. IOSR Journal of Pharmacy \& Biological Sciences, 12(6), 1-6.

29. Enitan, S. S., Ibeh, I. N., Akele, R. Y., Isitua, C. C., \& Idris, P. O. (2021). Phytochemical Screening \& Assessment of Antibacterial Activities of BioClean II Herbal Remedy on Some Selected Enteric Bacteria Isolates. African Journal of Traditional, Complementary \& Alternative Medicine (In Press).

30. Pasquarella, C., Pitzurra, O., \& Savino, A. (2000). The index of microbial air contamination (review). J Hosp Infect, 46, 241-256. 
Enitan S. S et al., Sch Int J Tradit Complement Med, Jan, 2022; 5(1): 7-18

31. ASHRAE. (2004). Thermal Environmental conditions for Human Occupancy, ASHRAE Standard 55. American Society of Heating, Refrigerating and Air-Conditioning Engineering, Atlanta. GA.

32. Adeleye, I. A., Ayolabi, C. I., Onobogu, C.C., Isawunmi, O. A., Nshiogu, M. E., \& Sobande, A. O. (2008). Antimicrobial activity of crude extracts of 12 medicinal plants and Epa-Ijebu (A wondercure concoction) used in South West Nigeria on common bacterial pathogens. Hamdard Medicus, 51, 32-39.

33. Adeleye, I. A., Ayolabi, C. I., Ejike, L. N., Abioye, A., \& Omonigbeyin, E. A. (2009). Antimicrobial \& Toxicology Studies of Epa-Ijebu. A "Wondercure" concoction used in South-west Nigeria. Afr. J. Infect. Dis, 3(1), 6-13.

34. Belonwu, D. C; Onyieke E. N., \& Oghenekaro, U. E. (2013). Phytochemical analysis of the Yoruba medicinal formulations- "Gbogbonise" and its effects on some liver enzymes. Indian Journal of Drugs \& Diseases, 2, 280-287.

35. Sofowora, A. (1993). Introduction to Medicinal Plants and Traditional Medicine. John Wiley \& Sons, New York, 1: 97-145.

36. Desai, S. D., Desai, D. G., \& Kaur, H. (2009). Saponins \& their Biological Activities. Pharm Times, 41(3), 13-16.

37. Ahmad, N. I., Rahman, A. S., Leong, Y., \& Azizul, N. H. (2019). A Review on the Phytochemicals of Parkia speciosa, Stinky Beans as Potential Phytomedicine. J Food Sci Nutr Re, 2(3), 151-173.

38. Lata, N., \& Dubey, V. (2010). "Flavnoids" J. Pharm. Res., 3(6), 1240-1242.
39. Brahim, L., Noureddine, G., Samir, H., \& Segni, Z. A. (2010). "Mechanism of action of tannins". Der Pharmacia Lettre, 2(6), 142-145.

40. Prassas, I., \& Diamandis, E. P. (2008). Novel therapeutic applications of cardiac glycosides. Nat Rev Drug Discov, 7(11), 926-935.

41. Morsy, N. M. (2017). Cardiac glycosides in Medicinal plants. In: Aromatic \& Medicinal Plants (Back to nature). INTECH. Department of Biochemistry, Jeddah, Saudia Arabia. pp. 29-45.

42. Edeoga, H. O., Okwu, D. E., \& Mbaebie, B. O. (2005). Phytochemical constituents of some Nigerian medicinal plants. Afr. J. Biotechnol, 4(7): 685-688.

43. Njoku, O. V., \& Obi, C. (2009). Phytochemical constituents of some selected medicinal plants. Afr. J. Pure Appl. Chem. 3(11): 228-223.

44. Adetumbi, M., Javor, G. T., \& Lau, B. H. (1986). Allium sativum (garlic) inhibits lipid synthesis by Candida albicans. Antimicrobial Agents Chemotheraphy, 3, 499-501.

45. Arora, D., \& Kaur, J. (1999). Antimicrobial activity of spices. International Journal of Antimicrobial agents, 12, 257-262.

46. Didry, N., Dubreuil, L., \& Pinkas, M. (1992). Antimicrobial activity of naphthaquinones and Allium extracts combined with antibiotics. Pharm Acta Helv, 67, 148-151.

47. Kanafani, Z. A., \& Perfect, J. R. (2008). Resistance to Antifungal Agents: Mechanisms and Clinical Impact. Clinical Infectious Diseases, 46(1), 120128.

48. Spampinato, C., \& Leonardi, D. (2013). "Candida Infections, causes, Targets, and Resistance Mechanisms: Traditional \& Alternative Antifungal Agents", BioMed Research International, pp: 1-13. 